\title{
HUBUNGAN PENERAPAN METODE TIM DENGAN KINERJA PERAWAT PELAKSANA DI RUANG NAKULA RSUD K.R.M.T WONGSONEGORO SEMARANG
}

\author{
Tri Ismu Pujiyanto, Muhammad Syahrul Basith \\ STIKES Karya Husada, Jl. R. Kompol Soekanto No, 46 Semarang, Telp./Fax (024) 6724581 \\ Email: syahrulbasith99@gmail.com
}

\begin{abstract}
ABSTRAK
Keperawatan adalah bagian yang tidak terpisahkan dari profesi kesehatan lain di dalam memberikan layanan kesehatan kepada klien. Keperawatan yang diberikan kepada pasien haruslah dilakukan dengan pelayanan profesional. Metode tim adalah metode yang paling banyak diterapkan oleh perawat dalam memberikan keperawatan. Penelitian ini bertujuan untuk mengetahui hubungan Penerapan Metode Tim Dengan Kinerja Perawat Pelaksana Di Ruang Nakula RSUD K.R.M.T Wongsonegoro Semarang. Penelitian kuantitatif dengan pendekatan Analitik Korelasional dan desain penelitian Cross Sectional. Instrument yang digunakan adalah kuesioner tentang penerapan metode tim dan kinerja perawat. Tehnik sampel yang digunakan adalah Cluster Sampling. Hasil penelitian menunjukkan nilai $p=0,005(p<0,05)$ yang berarti Ha diterima artinya ada hubungan Penerapan Metode Tim Dengan Kinerja Perawat Pelaksana. Ada hubungan Penerapan Metode Tim Dengan Kinerja Perawat Pelaksana. Bagi perawat perlu melakukan upaya peningkatan diri, baik pengetahuan maupun keterampilan melalui jenjang formal dan non formal guna mendukung upaya pencapaian kinerja yang lebih baik lagi.
\end{abstract}

Kata kunci : metode tim; kinerja perawat; perawat pelaksana

\begin{abstract}
Nursing is an integral part of other health professions in providing health services to clients. Nursing given to patients must be done with professional services. The team method is the method most widely applied by nurses in providing nursing. This research To determine relationship of the implementation of the team method with the performance of nursing implementation in the nakula room of K.R.M.T Wongsonegoro Hospital of Semarang. This research was quantitative research with a correlational analytical approach and cross sectional research design. The instrument used was a questionnaire about the application of team methods and nurse performance. The sample technique used is Cluster Sampling. The results showed the value of $p=0.005(p<0.05)$ which means that Ha is accepted, meaning that there is a relationship. Application of Team Methods With Performance of Implementing Nurses. The results of this study are that there is a relationship between the Application of Team Methods and the Performance of Implementing Nurses. For nurses, they need to make efforts to improve themselves, both knowledge and skills through formal and non-formal levels to support efforts to achieve better performance.
\end{abstract}

Keywords: team method; nurse performance; nursing implementation 


\section{LATAR BELAKANG}

Keperawatan adalah bagian yang tidak terpisahkan dari profesi kesehatan lain di dalam memberikan layanan kesehatan kepada klien. Keperawatan yang diberikan kepada pasien haruslah dilakukan dengan pelayanan profesional. Tindakan keperawatan ini disebut juga dengan pelayanan keperawatan profesional. Pelayanan keperawatan professional (professional nursing service) adalah rangkaian upaya melaksanakan system pemberian pelayanan asuhan keperawatan kepada masyarakat sesuai dengan kaidah - kaidah keperawatan sebagai profesi. Pelayanan keperawatan professional dilaksanakan diberbagai tatanan pelayanan kesehatan, menjangkau seluruh golongan dan lapisan masyarakat, maupun di tatanan pelayanan rumah sakit.

Metode tim adalah metode yang paling banyak diterapkan oleh perawat dalam memberikan keperawatan. Metode tim menggunakan tim yang terdiri atas anggota yang berbeda-beda, dalam memberikan asuhan keperawatan terhadap sekelompok pasien. Perawat di ruangan dibagi dalam 2-3 tim/grup yang terdiri atasVtenaga profesional, tenaga teknial, dan pembantu dalam satu grup kecil yang saling membantu.

Penelitian yang dilakukan oleh Direktorat Keperawatan Departemen Kesehatan Republik Indonesia bekerja sama dengan World Health Organization (WHO) tahun 2010 di Provinsi Kalimantan Timur, Sumatera Utara, Sulawesi Utara, Jawa Barat dan Daerah Khusus Ibukota (DKI) Jakarta menemukan bahwa $70 \%$ perawat selama 3 tahun terakhir tidak pernah mengikuti pelatihan, 39,8\% masih melakukan tugas-tugas kebersihan, 47,4\% perawat tidak memiliki uraian tugas dan belum dikembangkan monitoring dan evaluasi kinerja perawat khususnya mengenai keterampilan, sikap, kedisiplinan dan motivasi kerjanya.

Berdasarkan studi pendahuluan yang dilakukan penulis bulan September 2018 melalui teknik observasi dan wawancara dengan beberapa kepala ruang Rawat Inap RSUD K.R.M.T Wongsonegoro Semarang maka didapatkan fenomena bahwa semua ruang rawat inap sudah menerapkan metode asuhan keperawatan tim dengan benar, namun ada ruangan yang belum sesuai dengan pedoman penugasan asuhan keperawatan tim yang benar yaitu ruang Nakula.

Penerapan asuhan keperawatan metode tim di Ruang Nakula sudah dilaksanakan, sudah terdapat bagan struktur organiasasi metode tim, serta sudah ada surat keputusan sebagai ketua tim dan sebagai perawat pelaksana.Beberapa hal yang belum sesuai dengan penerapan metode tim adalah ketua tim belum semuanya di pimpin oleh perawat profesional, pembagian pertanggungjawaban pasien per tim belum seimbang satu tim hingga 10 orang pasien hal ini disebabkan masih kurangnya tenaga perawat sedangkan jumlah pasien masuk semakin meningkat, pelaksanaan ronde keperawatan di ruangan belum optimal. Hal ini dikarenakan jumlah pasien yang lebih banyak dari jumlah perawat. Berdasarkan latar belakang penilitian ini dilakukan untuk mengetahui hubungan penerapan Metode Tim dengan kinerja Perawat Pelaksana Di Ruang Nakula RSUD K.R.M.T Wongsonegoro Semarang.

\section{METODE}

Jenis ini adalah penelitian kuantitatif dengan pendekatan analitik korelasional dan desain cross sectional. Penelitian ini dilaksanakan tanggal 20 Maret 2019 sampai dengan 30 Agustus 2019 di Ruang Nakula RSUD K.R.M. T Wongsonegoro Semarang. Populasi dalam penelitian adalah perawat pelaksana di ruang Nakula sebanyak 18 perawat dengan menggunakn teknik purposive sampling. Instrument penelitian ini menggunakan kuesioner tentang metode tim dan kinerja perawat dan anlisa datanya menggunakan uji Chi Square.

\footnotetext{
HASIL

Analisa univariat berikut ini akan menjelaskan tentang karakteristik responden (umur, jenis kelamin dan pendidikan), metode tim responden dan kinerja perawat, uraiannya adalah sebagai berikut :
} 
Karakteristik responden menurut umur responden berdasarkan hasil analisis univariat dapat dilihat pada tabel 1 dibawah ini :

Tabel 1 Distribusi responden menurut umur responden di ruang Nakula RSUD K.R.M.T Wongsonegoro Semarang

\begin{tabular}{lcc}
\hline Umur & Frekuensi & Presentase (\%) \\
\hline $25-28$ & 10 & 55,5 \\
$29-32$ & 8 & 44,5 \\
\hline Total & 18 & 100 \\
\hline
\end{tabular}

Berdasarkan tabel 1 di atas menunjukkan bahwa sebagian besar responden berumur $25-28$ tahun yaitu sebanyak 10 orang $(55,5 \%)$.

Karakteristik responden menurut jenis kelamin dapat dilihat pada tabel 2 dibawah ini :

Tabel 2 Distribusi responden menurut jenis kelamin di ruang Nakula RSUD K.R.M.T Wongsonegoro Semarang

\begin{tabular}{lcc}
\hline Variabel & Frekuensi & Persentase (\%) \\
\hline Laki - Laki & 6 & 33,3 \\
Perempuan & 12 & 66,7 \\
\hline Total & 18 & 100 \\
\hline
\end{tabular}

Berdasarkan tabel 2 diatas menunjukkan bahwa sebagian besar responden berjenis kelamin perempuan yaitu sebanyak 12 responden $(66,7 \%)$.

Distribusi responden menurut pendidikan dapat dilihat pada tabel 3 dibawah ini:

Tabel 3.3 Distribusi responden menurut pendidikan perawat di ruang Nakula RSUD K.R.M.T Wongsonegoro Semarang

\begin{tabular}{lcc}
\hline variabel & Frekuensi & $\begin{array}{l}\text { Persentase } \\
(\%)\end{array}$ \\
\hline DIII Keperawatan & 14 & 77,8 \\
S1 Keperawatan & 4 & 22,2 \\
\hline
\end{tabular}
Total
18
100

Tabel 3 diatas menunjukkan bahwa sebagian besar pendidikan responden adalah DIII Keperawatan yaitu sebanyak 14 responden $(77,8$ $\%)$.

Distribusi responden menurut metode tim dapat dilihat pada tabel 4 dibawah ini :

Tabel 4 Distribusi responden menurut metode tim di ruang Nakula RSUD K.R.M.T Wongsonegoro Semarang

\begin{tabular}{lcc}
\hline Metode Tim & Frekuensi & \multicolumn{2}{c}{$\begin{array}{l}\text { Persentase } \\
(\%)\end{array}$} \\
\hline Baik & 15 & 83,3 \\
Kurang Baik & 3 & 16,7 \\
\hline Total & 18 & 100 \\
\hline
\end{tabular}

Hasil analisis didapatkan sebagian besar responden menerapkan metode tim dengan baik yaitu sebanyak 15 orang $(83,3 \%)$.

Distribusi responden menurut kinerja perawat dapat dilihat tabel 5 pada dibawah ini :

Tabel 5 Distribusi responden menurut kinerja perawat di ruang Nakula RSUD K.R.M.T Wongsonegoro Semarang

\begin{tabular}{lcc}
\hline Kinerja Perawat & Frekuensi & Persentase (\%) \\
\hline Baik & 4 & 22,2 \\
Cukup & 5 & 27,8 \\
Kurang & 9 & 50,0 \\
\hline Total & 18 & 100 \\
\hline
\end{tabular}

Tabel 5 di atas menunjukkan bahwa sebagian besar kinerja perawat kurang yaitu sebanyak 9 orang (50\%).

Analisa bivariat dalam penelitian ini adalah hubungan antara metode tim dengan kinerja perawat pelaksana diruang Nakula RSUD K.R.M.T Wongsonegoro Semarang. Analisa data dengan menggunakan Uji Chi Square didapatkan hasil sebagai berikut :

Tabel 6 Distribusi responden berdasarkan hubungan metode tim dengan kinerja perawat di ruang Nakula RSUD K.R.M.T Wongsonegoro Semarang

\begin{tabular}{lcccccccc}
\hline \multicolumn{9}{c}{ Kinerja Perawat } \\
\hline Metode Tim & Baik & $\%$ & Cukup & $\%$ & Kurang & $\%$ & Jumlah & $\%$ \\
\hline Baik & 1 & 5,5 & 5 & 27,8 & 9 & 50 & 15 & 83, \\
& & & & & & & & 3 \\
Kurang baik & 3 & 16,7 & 0 & 0 & 0 & 0 & 3 & $\begin{array}{c}16 \\
7\end{array}$ \\
\hline Total & 4 & 22.2 & 5 & 27,8 & 9 & 50 & 18 & 100 \\
\hline
\end{tabular}


Berdasarkan tabel 6 di atas di dapatkan bahwa sebagian besar penerapan metode tim baik dengan kinerja perawat kurang yaitu sebanyak 9 orang (50\%). Hasil tabel 6 di atas tidak memenuhi syarat uji chi square karena ada 2 cell yang frekuensi kenyataannya sebesar 0 sehingga cell di marger menjadi tabel $2 \times 2$ sebagai berikut:

Tabel 7 Distribusi responden berdasarkan hubungan metode tim dengan kinerja perawat di ruang Nakula RSUD K.R.M.T Wongsonegoro Semarang

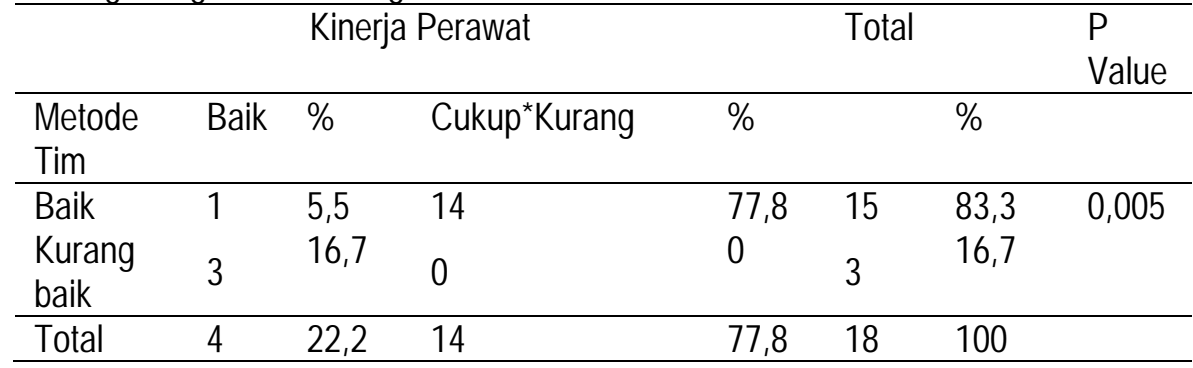

Setelah di merger menjadi tabel 2x2 masih tetap ada 1 cell yang frekuensi kenyataannya sebesar 0 sehingga syarat chi square masih tidak terpenuhi dan uji yang dipakai adalah uji Fisher exact. Hasil penelitian di dapatkan bahwa sebagian besar responden menerapkan metode tim baik dengan kinerja cukup kurang yaitu sebanyak 14 orang (83,3\%). Hasil uji fisher exact menunjukkan nilai p value 0,005 ( $p<$ $0,05)$ yang berarti bahwa ada hubungan antara penerapan metode tim dengan kinerja perawat pelaksana.

\section{PEMBAHASAN}

Hasil penelitian menunjukkan bahwa sebagian besar responden berumur $25-28$ tahun yaitu sebanyak 10 orang $(55,5 \%)$. Umur berkaitan erat dengan tingkat kedewasaan. Ma'wah (2015) mengatakan bahwa Seorang lebih dewasa cenderung memiliki keterampilan dan kemampuan serta prestasi kerja dibanding usia dibawahnya. Meningkatnya usia seseorang seringkali berbanding lurus dengan pengalaman dan membaiknya kinerja individu. Hal ini di dukung dengan penelitian yang dilakukan oleh Nining Rusminingsih (2012) yang menyatakan bahwa umur memiliki hubungan yang signifikan dengan kerja perawat. Semakin tua umur semakin baik pula tingkat kinerjanya.

Hasil penelitian menunjukkan bahwa sebagian besar responden berjenis kelamin perempuan yaitu sebanyak 12 responden $(66,7 \%)$. Hal ini sesuai dengan teori yang di kemukakan oleh Morrow dalam Ma'wah, (2015) mengatakan bahwa salah satu faktor yang mempengaruhi kinerja adalah karakteristik individu dimana profesi keperawatan 90\% dipegang oleh kaum wanita lebih dapat berpengaruh kepada pasien, individu, kelompok dan masyarakat yang disebabkan wanita memiliki rasa sosial yang tinggi. Dalam Musta'an
(2012) juga dikatakan bahwa pada dasarnya ilmu keperawatan adalah mother instinc atau dunia keperawatan identik dengan wanita atau ibu. Hasil penelitian ini sejalan dengan penelitian yang dilakukan oleh Sari Madonni, (2015) yang menunjukkan bahwa jenis kelamin berpengaruh terhadap pemberian asuhan keperawatan pada pasien di ruang rawat inap RSUD Dr. Arifin Achmad Riau.

Hasil Penelitian menunjukkan bahwa sebagian besar pendidikan responden adalah DIII Keperawatan yaitu sebanyak 14 responden (77,8 \%). Menurut Rusmianingsih (2012), perawat dengan tingkat pendidikan yang berbeda mempunyai peluang untuk mempunyai kepuasan kerja yang berbeda pula karena semakin tinggi tingkat pendidikan maka kemampuan kognitif dan keterampilan akan semakin meningkat sesuai dengan kompetensinya sehingga peluang dan kesempatan untuk mendapatkan posisi dan promosi yang lebih baik akan semakin meningkat pula. Hal ini sesuai dengan penelitian yang dilakukan oleh Ake R.C. Langingi, (2015) bahwa mayoritas perawat rawat inap berpendidikan D3 keperawatan. Perawat yang pendidikannya berbeda - beda memiliki tingkat kemampuan dan pengetahuan yang berbeda. Latar belakang pendidikan seseorang akan mempengaruhi 
pengetahuan, cara pandang dan sikapnya dalam bekerja.

Hasil penelitian ini menunjukkan bahwa sebagian besar responden melakukan metode tim dengan baik yaitu sebanyak 15 orang $(83,3 \%)$. Hal ini sesuai dengan teori yang menyatakan bahwa ada beberapa elemen yang penting yang dapat mempengaruhi penerapan metode tim menjadi optimal bahkan kurang optimal yaitu kepemimpinan, komunikasi, koordinasi, penugasan dan supervisi. Anggota tim harus menghargai kepemimpinan ketua tim karena ketua tim membantu anggotanya untuk memahami dan melakukan tugas sesuai dengan kemampuan mereka. Hasil penelitian ini sejalan dengan penelitian Mar'ah Tusalleha (2014) mengenai penerapan metode tim dimana ada hubungan yang bermakna antara hubungan interpersonal, komunikasi, tanggunggung jawab dengan kinerja perawat pelaksana diruang rawat inap interna di RSUD Daya Kota Makassar.

Hasil penelitian menunjukkan bahwa sebagian besar kinerja perawat kurang yaitu sebanyak 9 orang (50\%). Hal ini disebabkan karena rendahnya tingkat efektivitas dan efesiensi atau tingkat keberhasilan perawat dalam melaksanakan tugas yang menjadi tanggung jawabnya. Secara umum dapat dikatakan kinerja merupakan ukuran keberhasilan suatu organisasi dalam mencapai tujuan. Namun keberhasilan suatu organisasi tidak terlepas dari pengaruh struktural organisasi yang tepat, pembagian wewenang dan tanggung jawab yang jelas dari para pelaku atau faktor yang berkecimpung dalam organisasi tersebut. Tanggung jawab akan tugas berkaitan dengan disiplin dan inisiatif para pekerja, hal ini akan mencerminkan kreativitas yang bernuansa daya dorong (motivasi) dalam mencapai tujuan organisasi yang lebih baik.

Kinerja buruk dapat disebabkan karena adanya unsur dari dalam dan luar diri tenaga perawat yang mempengaruhi psikologis sehingga menurunkan semangat kerja dalam rangka pemenuhan pelayanan keperawatan di rumah sakit. Unsur dalam diri individu ini mencakup pengetahuan, kepercayaan dan kenyamanan. Sedangkan unsur di luar diri individu mencakup hubungan interpersonal dengan rekan kerja, adanya konflik internal organisasi dan kurangnya dukungan dari rumah sakit untuk perawat dapat melaksanakan tugas dan tanggung jawabnya dengan baik. Unsur dalam diri individu ditambah dengan adanya hasil penerapan keterampilan dan pertimbangan yang efektif dalam memberikan pelayanan keperawatan dapat meningkatkan kompetensi perawat sehingga dapat mempengaruhi kinerja perawat. Hasil penelitian ini di dukung oleh penelitian yang dilakukan oleh Amalia Anita (2018) yang menyatakan bahwa ada hubungan yang bermakna antara penerapan metode tim dengan kinerja perawat pelaksana di ruang rawat inap RSUD dr. $H$. Moch Ansari Saleh Banjarmasin dengan nilai $p=0,000<a=0,05$.

Hasil uji chi square pada penelitian ini menunjukkan bahwa nilai $p=0,005(p<0,05)$ yang berarti bahwa ada hubungan antara metode tim dengan kinerja perawat pelaksana. Hal ini disebabkan karena kinerja perawat di pengaruhi oleh bebarapa faktor yang mampu mendukung keberhasilan pelaksanaan metode tim. Penerapan metode tim menggunakan tim yang terdiri dari anggota yang berbeda - beda dalam memberikan asuhan keperawatan terhadap sekelompok pasien. Perawat ruangan dibagi menjadi 2-3 tim/group yang terdiri dari perawatan profesional, tehnikal dan pembantu dalam satu group kecil yang saling membantu. Metode ini didasarkan pada keyakinan bahwa setiap anggota kelompok mempunyai kontribusi dalam merencanakan dan memberikan asuhan keperawatan sehingga timbul motivasi dan rasa tanggung jawab perawat yang tinggi.

Metode tim bisa berjalan dengan baik jika faktor - faktor yang mempengaruhi kinerja perawat terpenuhi dengan baik. Kinerja adalah hasil yang dicapai atau prestasi yang dicapai karyawan dalam melaksanakan suatu pekerjaan dalam suatu organisasi. Penilaian kinerja merupakan alat ukur yang paling dapat dipercaya oleh Manajer perawat dalam mengontrol sumber daya manusia dan produktivitas. Proses penilaian kinerja dapat digunakan secara efektif dalam mengarahkan perilaku pegawai dalam rangka menghasilkan jasa keperawatan yang 
berkualitas tinggi. Perawat Manajer dapat menggunakan proses penilaian kinerja untuk mengatur arah kerja, melatih, bimbingan perencanaan karir, serta pemberian penghargaan kepada perawat yang berkompeten.

Model teori kinerja dan melakukan analisis terhadap sejumlah variabel yang mempengaruhi perilaku dan kinerja individu. Variabel yang mempengaruhi kinerja adalah individu, perilaku, psikologi dan organisasi, meliputi (1) Variabel individu dikelompokan pada sub variabel kemampuan dan ketrampilan, latar belakang dan demografis merupakan faktor utama yang mempengaruhi perilaku dan kinerja individu, (2) Variabel psikologi terdiri dari sub variabel persepsi, sikap, kepribadian, belajar dan motivasi. Variabel ini dipengaruhi oleh keluarga, tingkat sosial pengalaman kerja sebelumnya dan variabel demografis dan (3) Variabel organisasi, mempunyai efek tidak langsung terhadap perilaku dan kinerja individu. Variabel organisasi digolongkan dalam sub variabel sumber daya, kepemimpinan, imbalan, struktur dan desain pekerjaan. Sub Variabel imbalan akan berpengaruh untuk meningkatkan motivasi kerja yang pada akhirnya secara langsung akan meningkatkan kinerja individu.

Hasil penelitian di dukung oleh penelitian yang dilakukan oleh Eko Nur Pujiyanto (2018) yang menyatakan bahwa ada hubungan metode tim dengan kinerja perawat pelaksana di Rumah sakit PKU Muhammadiyah Bantul.

\section{KESIMPULAN DAN SARAN}

Sebagian besar responden berumur 25 - 28 tahun yaitu sebanyak 10 orang. Sebagian besar responden berjenis kelamin perempuan yaitu sebanyak 12 responden. Sebagian besar pendidikan responden adalah DIII Keperawatan yaitu sebanyak 14 responden. Sebagian besar responden menerapkan metode tim dengan baik yaitu sebanyak 15 orang. Sebagian besar kinerja perawat kurang yaitu sebanyak 9 orang. Ada hubungan antara penerapan metode tim dengan kinerja perawat pelaksana di ruang nakula RSUD K.R.M.T Wongsonegoro Semarang $(p=0,005)$. Pasien perlu memberi masukan kepada perawat tentang pelayanan yang diberikan sehingga mampu memperbaiki kinerjanya dan pelayanan yang diberikan bisa menimbulkan rasa puas dan nyaman. Perawat perlu melakukan upaya peningkatan diri, baik pengetahuan maupun keterampilan melalui jenjang formal dan non formal guna mendukung upaya pencapaian kinerja yang lebih baik lagi. Bidang keperawatan RSUD K.R.M.T Wongsonegoro Semarang diharapkan meninjau kembali kinerja perawat dengan mempertimbangkan aspek $5 \mathrm{M}$ yang terdiri dari perawat itu sendiri, gaji, metode asuhan keperawatan yang dipakai dan pasien demi tercapainya keberhasilan dalam suatu manajemen rumah sakit.

\section{REFERENSI}

Ake R.C. Langingi, (2015). Hubungan Faktor Internal Dan Eksternal Dengan Kinerja Perawat Pelaksana Di Instalasi Rawat Inap C RSUP Prof. Dr. R.D Kandau Manado. Di akses 6 Agustus 2018

Amalia Anita (2018). Hubungan Penerapan Metode Tim Dengan Kinerja Perawat Pelaksana Di Ruang Rawat Inap RSUD Dr. H. Moch Ansari Saleh Banjarmasin

DEPKES. RI. (2010). Kebutuhan Dasar Manusia Dan Proses Keperawatan. Jakarta: Akademi Keperawatan.

Eko Nur Pujiyanto (2018). Hubungan Metode Tim Dengan Kinerja Perawata Pelaksana Di Rumah Sakit PKU Muhammadiyah Bantul

Hidayat, A. (2014). Metode Penelitian Keperawatan Dan Teknik Analisis Data. Jakarta: Salemba Medika.

Kusnanto. (2010). Pengantar Profesi Dan Praktik Keperawatan Profesional. Jakarta: EGC

Mar'ah Tusalleha (2014). Hubungan Penerapan Metode Tim Dengan Kinerja Perawat Pelaksana Diruang Rawat Inap Interna di RSUD Daya Kota Makassar

Miftakhul Ma'wah. (2015). Faktor-Faktor yang Berhubungan dengan Kinerja Perawat di Ruang Rawat Inap Rumah Sakit Umum Kota Tangerang Selatan. Skripsi Mahasiswa Universitas 
Islam Negeri Syarif Hidayahtullah Jakarta

Musta'an Nuning. (2012). Faktor-Faktor Yang Mempengaruhi Motivasi Kerja Perawat Di Rumah Sakit Jiwa Daerah Surakarta

Nining Rusmianingsih, (2012). Hubungan Penerapan Metode Asuhan Keperawatan Tim Dengan Kepuasan Kerja Perawat Di Instalasi Rawat Inap RSU Kabupaten Tangerang. Di akses 5 Agustus 2018

Sari Madonni, (2015). Hubungan penerapan metode tim dengan rencana asuhan keperawatan pasien di ruang rawat inap RSUD Dr. Arifin Achmad Riau. Di akses 6 Agustus 2018

Triwibowo. (2013). Manajemen pelayanan keperawatan di rumah sakit. Jakarta: TIM.

World Health Organization. (2013). Protecting Workers' Health Preventing Musculoskeletal Disorders in the Workplace. Diambil dari http://www.who.int/occupational health/p ublications/muscdisorders/en/. 